\title{
Effective fraction of Bletilla striata reduces the inflammatory cytokine production induced by water and organic extracts of airborne fine particulate matter $\left(\mathrm{PM}_{2.5}\right)$ in vitro
}

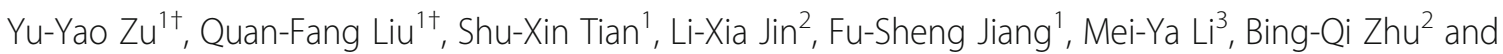
Zhi-Shan Ding ${ }^{2^{*}}$

\begin{abstract}
Background: Bletilla striata is a traditional Chinese medicine used to treat hemorrhage, scald, gastric ulcer, pulmonary diseases and inflammations. In this study, we investigated bioactivity of the effective fraction of B. striata (EFB) in reducing the inflammatory cytokine production induced by water or organic extracts of $\mathrm{PM}_{2.5}$.

Methods: $\mathrm{PM}_{2.5}$ extracts were collected and analyzed by chromatographic system and inductively coupled plasma mass spectrometer. Cell viability was measured using MTS (3-(4,5-dimethylthiazol-2-yl)-5-(3-carboxymethoxyphenyl)-2(4-sulfophenyl)-2H-tetrazolium) assay, and cell supernatant was analyzed by flow cytometry, ELISA, and qRT-PCR in cultured mouse macrophage cell line RAW264.7 treated with EFB and PM 2.5 extracts. Expressions of nuclear factorkappa B (NF-kB) and mitogen-activated protein kinase (MAPK) signaling pathway were measured by Western blot.
\end{abstract}

Results: $\mathrm{PM}_{2.5}$ composition is complex and the toxicity of $\mathrm{PM}_{2.5}$ extracts were not noticeable. The treatment of EFB at a wide dose-range of $0-40 \mu \mathrm{g} / \mathrm{mL}$ did not cause significant change of RAW264.7 cell proliferation. EFB pretreatment decreased the inflammatory cytokines in the macrophage. Further analysis showed that EFB significantly attenuated $\mathrm{PM}_{2.5}$-induced proinflammatory protein expression and downregulated the levels of phosphorylated NF-kBp65, inhibitor of kappa B (IKB)-a, c-Jun N-terminal kinase (JNK), extracellular signal-regulated kinase (ERK), and p38.

Conclusions: Our study demonstrated the potential effectiveness of B. striata extracts for treating $\mathrm{PM}_{2.5}$-triggered pulmonary inflammation.

Keywords: Bletilla striata (Thunb.) Rchb.F., PM 2.5 extracts, Macrophage, Inflammation, NF-KB/MAPK pathway

\section{Background}

Airborne fine particulate matter $\left(\mathrm{PM}_{2.5}\right)$ poses a high risk to human health worldwide. Epidemiological studies have shown that exposure to $\mathrm{PM}_{2.5}$ is strongly related to chronic bronchitis, asthma, chronic obstructive pulmonary disease (COPD), emphysema, lung cancer, and other respiratory diseases [1-3]. The components of $\mathrm{PM}_{2.5}$ are complicated and

\footnotetext{
* Correspondence: dzszjtcm@163.com

${ }^{\dagger}$ Yu-Yao Zu and Quan-Fang Liu contributed equally to this work.

${ }^{2}$ College of Medical Technology, Zhejiang Chinese Medical University,

Zhejiang 310053, Hangzhou, China

Full list of author information is available at the end of the article
}

they have been reported to include water-soluble inorganics, toxic metals, polycyclic aromatic hydrocarbons (PAHs), and bacterial endotoxins [4]. Pulmonary macrophage-mediated inflammation plays a vital role in $\mathrm{PM}_{2.5}$-induced pulmonary dysfunction $[5,6]$. The transcription nuclear factor-kappa $\mathrm{B}$ $(\mathrm{NF}-\mathrm{kB})$ is closely associated with inflammatory cytokine production in pulmonary macrophages [7]. The NF-kB heterodimer involving Rel (p65) and p50 proteins is a latent cytoplasmic factor that can be found in the cytosol complexed with the inhibitory protein inhibitor of kappa B (IkB)- $\alpha[8]$. Upon stimulation, IkB $\alpha$ dissociates from the heterodimer, which enables the heterodimer to translocate into

(c) The Author(s). 2019 Open Access This article is distributed under the terms of the Creative Commons Attribution 4.0 International License (http://creativecommons.org/licenses/by/4.0/), which permits unrestricted use, distribution, and reproduction in any medium, provided you give appropriate credit to the original author(s) and the source, provide a link to the Creative Commons license, and indicate if changes were made. The Creative Commons Public Domain Dedication waiver (http://creativecommons.org/publicdomain/zero/1.0/) applies to the data made available in this article, unless otherwise stated. 
the nucleus where it binds to specific DNA sequences, e.g., the interleukin (IL)- 6 and tumor necrosis factor (TNF)- $\alpha$ promoters. In addition, mitogen-activated protein kinase (MAPK), including extracellular signal-regulated kinase (ERK), c-Jun N-terminal kinase (JNK), and p38 kinase, are also activated in $\mathrm{PM}_{2.5}$-treated macrophages [9-11]. Activated MAPK can upregulate inflammatory cytokine expression via phosphorylation of the downstream transcription factor, activator protein-1 (AP-1). Therefore, the NF- $\mathrm{kB}$ and MAPK pathways are key targets for the treatment of $\mathrm{PM}_{2.5}$ induced pulmonary inflammation and dysfunction [12].

Bletilla striata (Thunb.) Rchb. f., which is a traditional Chinese medicine, has been widely used for its pulmonary protective, hemostasis, analgesic, antiulcer, anti-fibrosis, and anti-inflammatory effects [13-15]. Numerous reports have demonstrated the exitance of various chemical components of $B$. striata, including bibenzyls, phenanthrenes, polysaccharides, anthocyanidins, dihydrophenanthrenes, steroids, triterpenes, and glycosides [16], which exhibit a variety of biological and pharmacological activities. For instance, B. striata polysaccharide was reported to reduce the levels of pro-inflammatory cytokines and suppress MAPK/NF- $\mathrm{KB}$ signaling pathway activity in rats with gastric ulcer induced by ethanol [17]. In our previous study, we used to carried out the utilization probability of the fibrous root part of $B$. striata, studied the pharmacological activities of B. striata extract [18], exploring the effects of antiviral and antibacterial activity, purifying the total effective fraction of B. striata (EFB) and efficacy components [19], and obtaining it's extracts using a liquid chromatography silica gel column and semipreparative liquid chromatography [20]. At the same time, experimental results obtained in vitro cell system analysis confirmed the antioxidant activity of $B$. striata, which can induce HepG2 cells apoptosis in a dose-dependent manner [21]. Studies have shown that $\mathrm{PM}_{2.5}$ could trigger pulmonary inflammation and oxidative stress, which result in pulmonary fibrosis [22, 23], our previous experiments have documented that the ethanol extract of B. striata exhibited a variety of therapeutic effects including antiinflammatory, and anti-fibrosis by significantly down regulated serum levels of IL-1 $\beta$, TNF- $\alpha$, transforming growth factor-(TGF- $\beta$ ) and other inflammatory factors $[24,25]$, and are more effective than the polysaccharide of B. striata [26]. Besides this, a recent study by Luo [27] showed that the polysaccharide of $B$. striata decreased the inflammatory cytokine levels of IL- 6 and TNF- $\alpha$ to protect IEC-18 cells from lipopolysaccharide (LPS)-induced injury. Hence, we speculated that the extract of B. striata can impact $\mathrm{PM}_{2.5}$-induced injury.

In recent years, a large number of scientific studies, including clinical trials, have been conducted in the field of traditional Chinese medicine, and it has been found that B. striata and extracts have anti-inflammatory and anti-oxidative effects $[28,29]$. The effect of anti- $\mathrm{PM}_{2.5}$ induced inflammation by $B$. striata has not been reported. 2,7-dihydroxy-4-methoxy-9,10-dihydrophenanthrene (Coelonin), as one of the main active components from $B$. striata total ethanol-extract (BTE) was separated and can significantly down regulated IL- $1 \beta$ and IL-6 expression on LPS-induced RAW264.7 cells [25]. Therefore, Coelonin may be one of the main active components contributing to the anti-inflammatory of $B$. striata. The study was to explore the protective effects of BTE and Coelonin on $\mathrm{PM}_{2.5}$-induced inflammatory cytokine expression in macrophages and investigate the underlying mechanism of the prevention and treatment effects of B. striata regarding $\mathrm{PM}_{2.5}$-related inflammatory disease.

\section{Methods}

\section{Preparation and chemical analyses of $\mathrm{PM}_{2.5}$}

The particles were deposited on $203 \mathrm{~mm} \times 254 \mathrm{~mm}$ glass fiber filters purchased from Whatman (Little Chalfont, Buckinghamshire, UK), which had been prebaked at $300{ }^{\circ} \mathrm{C}$ for $5 \mathrm{~h}$ before use. Samples of $\mathrm{PM}_{2.5}$ were collected on glass fiber filters using a Thermo Anderson G2.5 large-volume sampler (Waltham, MA, USA) with a flow rate of $1.13 \mathrm{~m}^{3} / \mathrm{min}$. The sampling location was set on the rooftop of laboratory building 4 at the Zhejiang Chinese Medical University, which was $20 \mathrm{~m}$ higher above the ground, without obvious nearby source of pollution, from October 1, 2016 to March 3, 2017.

For water extraction, small pieces of the glass fiber filter $(0.5 \times 0.5 \mathrm{~cm})$ were cut and immersed in ultrapure water. For organic extraction, small pieces of the glass fiber filter $(0.5 \times 0.5 \mathrm{~cm})$ were cut and immersed in dichloromethane. These samples were sonicated for $6 \times 30$ $\mathrm{min}$. Water extracts were filtered through $0.45 \mu \mathrm{m}$ filters and freeze-dried, while organic extracts were rotaryevaporated, and stored at $-80^{\circ} \mathrm{C}$ for later use. Water extracts of $\mathrm{PM}_{2.5}$ (WEP) were then diluted to $10 \mathrm{mg} / \mathrm{mL}$ using phosphate-buffered saline (PBS) buffer, while organic extracts of $\mathrm{PM}_{2.5}$ (OEP) were diluted in dimethyl sulfoxide (DMSO)/sterile PBS (with a final DMSO concentration $<0.5 \%)$. The stock solution was sonicated for $45 \mathrm{~min}$ before the experiment and then further diluted to the desired concentration with Dulbecco's Modified Eagle Medium (DMEM; CellMax, Beijing, China).

Water-soluble inorganic ions, including $\mathrm{Na}^{+}, \mathrm{K}^{+}$, $\mathrm{Mg}^{2+}, \mathrm{Ca}^{2+}, \mathrm{NH}_{4}{ }^{+}, \mathrm{SO}_{4}{ }^{2-}, \mathrm{NO}_{3}{ }^{-}$, and $\mathrm{Cl}^{-}$in the $\mathrm{PM}_{2.5}$ water extract was analyzed using an ICS-2000 ion chromatography system (Dionex, USA) equipped with an AS3000 autosampler. Ion standard materials were purchased from the National Standards Center (Beijing, China). A total of 20 kinds of soluble metals were detected in the water extracts using an inductively coupled plasma mass spectrometer (ICP-MS; Thermo X series; 
Thermo Fisher Scientific, Waltham, MA, USA). The analytical model involved a full quantitative analysis; the oxide level was $<2 \%$; the double charge formation was $<$ $3 \%$. The samples were analyzed under the above optimized conditions, and rhenium were used as internal standards. A 7890A-5975C gas chromatography-mass spectrometer (GC-MS; Agilent Technologies, Santa Clara, CA, USA) equipped with an electron ionization (EI) ion source was used to conduct PAHs analysis in the organic extracts [30]. Blank filters were analyzed to check for chemical contamination during the field and laboratory operations.

\section{Preparation of $B$. striata effective fraction}

B. striata was collected from Meichuan Town in Hubei Province, People's Republic of China, and authenticated as a purple orchid with medicinal properties by Prof. Zhi-Shan Ding (one of the authors). A voucher specimen (LA-20161103) has already been deposited in Zhejiang Chinese Medical University. The dry tubers of B. striata were processed, smashed, and filtered through a 40mesh sieve. $100 \mathrm{~g}$ powder was refluxed and extracted three times with $1 \mathrm{~L}$ of $95 \%$ ethanol. The filtrate was allowed to cool, filtered, and dried in the reduced pressure distillation. The obtained semi-solid $B$. striata total ethanol-extract (BTE) was stored at $-20^{\circ} \mathrm{C}$ until used.

The BTE was loaded onto a polyamide resin column and washed with distilled water, followed by elution with $40 \%(\mathrm{v} / \mathrm{v})$ ethanol. The active fraction eluted with $40 \%$ ethanol in water were dried in vacuum and analyzed using a Dionex Ultimate3000 high-performance liquid chromatography (HPLC, USA), then, separation and purification were carried out by Dionex Ultimate3000 semi-preparative high-performance liquid chromatography (semi-preparative HPLC, USA). A Welch Ultimate $\mathrm{XB}-\mathrm{C}_{18}$ column $(10 \times 250 \mathrm{~mm}, 10 \mu \mathrm{m})$ was used with the column temperature set at $30^{\circ} \mathrm{C}$, and elution solvents were acetonitrile with $0.1 \%$ formic acid. Analytes were monitored at $280 \mathrm{~nm}$. The peaks with a retention time of 12.5 15.5 min was collected to obtain the extract of BTE, and analyzed by HPLC fingerprints and SYNAPT G2-Si HD Mass Spectrometer (Waters, USA) to identify the extract as Coelonin (Additional file 1). $5 \mathrm{mg} / \mathrm{mL}$ BTE and Coelonin were diluted using DMSO, which were further diluted to desired concentrations with DMEM in experiment (with a final DMSO concentration $<0.5 \%$ ).

\section{Cell culture}

The mouse macrophage cell line RAW264.7 was purchased from Shanghai Institutes for Life Science, Chinese Academy of Sciences (Shanghai, China). The RAW264.7 cells were cultured in DMEM containing $10 \%$ fetal bovine serum (FBS), which was obtained from CellMax, supplemented with 100 units/mL penicillin and
$100 \mathrm{mg} / \mathrm{mL}$ streptomycin at $37^{\circ} \mathrm{C}$ in a humidified $5 \%$ $\mathrm{CO}_{2}$ atmosphere. The cells were passaged every 2-3 days, after reaching $70-80 \%$ confluency.

\section{Cell viability analysis}

RAW264.7 cells were plated in a 96-well plate at a density of $5 \times 10^{4}$ cells per well. After overnight growth, the culture medium was removed. To assess the effects on cell viability, $100 \mu \mathrm{L}$ of cell culture medium containing either $\mathrm{PM}_{2.5}$ water or organic extracts at $12.5,25,50$, 100 , and $200 \mu \mathrm{g} / \mathrm{mL}$ were added to each well, and either BTE or Coelonin at $1.25,2.5,5,10,20$, and $40 \mu \mathrm{g} / \mathrm{mL}$ were added. After $24 \mathrm{~h}$ of incubation, $20 \mu \mathrm{L}$ MTS (3-(4, 5-dimethylthiazol-2-yl)-5-(3-carboxymethoxyphenyl)-2(4-sulfophenyl)-2H-tetrazolium); Promega, Madison, WI, USA) was added to each well for $2 \mathrm{~h}$ of incubation at $37^{\circ} \mathrm{C}$ in a humidified $5 \% \mathrm{CO}_{2}$ incubator. The absorbance at $490 \mathrm{~nm}$ of the formazan was assessed using a BioTek Epoch2 microplate reader (Winooski, VT, USA).

\section{Measurement of TNF- $a$, IL-6, and monocyte chemoattractant protein (MCP)-1}

RAW264.7 cells were plated in a 96-well plate at a density of $1 \times 10^{5}$ cells per well in $100 \mu \mathrm{L}$ of culture media and incubated for $12 \mathrm{~h}$. Subsequently, the differentiated RAW264.7 cells were treated with $\mathrm{PM}_{2.5}$ at different concentrations of $12.5,25,50,100$, and $200 \mu \mathrm{g} / \mathrm{mL}$ for an additional 12 and $24 \mathrm{~h}$. The supernatant of the $\mathrm{PM}_{2.5}$ extract-treated cells was collected to assess TNF- $\alpha$ secretion using an enzyme-linked immunosorbent assay (ELISA) obtained from eBioscience (San Diego, CA, USA).

Further, other cells were pretreated with BTE at $0,2.5$, 5,10 , and Coelonin at $0,1.25,2.5,5$, and $10 \mu \mathrm{g} / \mathrm{mL}$ for $2 \mathrm{~h}$ before treating with $200 \mu \mathrm{g} / \mathrm{mL} \mathrm{PM}_{2.5}$ water extract, in another group, same treatments by BTE and Coelonin were repeated and followed by treating with $100 \mu \mathrm{g} / \mathrm{mL}$ organic extract. After $18 \mathrm{~h}$ treatment, the supernatant of these cells was then collected for the analysis of TNF- $\alpha$, IL-6, and MCP-1 secretion using an ELISA and a BD Biosciences cytometric bead array assay (San Jose, CA, USA). Each immunoassay was performed in accordance with the manufacturer's instructions.

\section{Quantitative real-time PCR (qRT-PCR) analysis}

Total RNA was extracted with RNAiso Plus (Takara, Tokyo, Japan) according to the manufacturer's instruction, and dissolved in $30 \mu \mathrm{L}$ diethylpyrocarbonate (DEPC) $-\mathrm{H}_{2} \mathrm{O}$. The total RNA was reverse-transcribed to cDNA using a PrimeScript ${ }^{\text {mi }}$ RT Master Mix kit (Takara, Shiga, Japan). Relative expression levels of IL-6 and TNF- $\alpha$ were quantified using SYBR ${ }^{\bullet}$ Premix Ex Tap ${ }^{\text {Ts }}$ II (Takara, Shiga, Japan). All primer sequences (Sangon Biotech, Shanghai, China) are listed in Table 1. PCR 
cycle were conducted according to the following conditions: initial denaturation at $95^{\circ} \mathrm{C}$ for $2 \mathrm{~min}, 40$ cycles of denaturation at $95^{\circ} \mathrm{C}$ for $15 \mathrm{~s}$, annealing at $60^{\circ} \mathrm{C}$ for 20 $\mathrm{s}$, and extension at $72{ }^{\circ} \mathrm{C}$ for $15 \mathrm{~s}$. Relative gene expression levels, obtained based on reverse transcription qRTPCR, were calculated using the $2^{-\Delta \Delta C t}$ method following normalization to glyceraldehyde 3-phosphate dehydrogenase (GAPDH).

\section{Western blot analysis}

For the western blot analysis, the $\mathrm{PM}_{2.5}$ water extract at a concentration of $200 \mu \mathrm{g} / \mathrm{mL}$ was used and the $\mathrm{PM}_{2.5}$ organic extract at a concentration of $100 \mu \mathrm{g} / \mathrm{mL}$ was used. Total proteins were isolated using a protein extraction kit (Beyotime, Shanghai, China). Harvested proteins were denatured at $95{ }^{\circ} \mathrm{C}$ for $10 \mathrm{~min}$, separated by sodium dodecyl sulfate polyacrylamide gel electrophoresis (SDSPAGE), and then transferred onto a polyvinylidene fluoride (PVDF) membrane (Millipore Corp., USA). The membranes were blocked with $5 \%$ bovine serum albumin (BSA; Biosharp, Hefei, China) for $1 \mathrm{~h}$. They were subsequently probed at $4{ }^{\circ} \mathrm{C}$ overnight with the primary antibodies, comprising anti- $\beta$-actin (110000); anti-ІкB $\alpha$

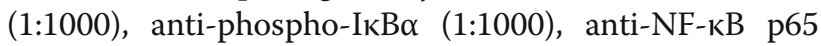
(15000), anti-phospho-NF-kBp65 (1:2000), anti-p38 (1: 2000), anti-phospho-p38 (1:1000), anti-JNK1 + JNK2 + JNK3 (1:2000), anti-phospho-JNK1 + JNK2 + JNK3 (1: 1000), anti-ERK1 + ERK2 (1:2000) and anti-phosphoERK1 + ERK2 $(1,1000)$ purchased from Abcam (Cambridge, MA, UK). Subsequently, the membranes were incubated for $1 \mathrm{~h}$ with a horseradish peroxidase (HRP)conjugated secondary antibody (15,000, Jackson ImmunoResearch Laboratories, West Grove, PA, USA) at room temperature. Enhanced chemiluminescence (ECL) substrate (Perkin Elmer, Waltham, MA, USA) was added to detect the proteins using a chemiluminescence imaging system (C-DiGit Blot Scanner, LI-COR, USA).

\section{Statistical analysis}

All data are presented as mean \pm standard deviation. A statistical comparison of the between-group differences was performed using one-way analysis of variance (ANOVA) in SPSS17.0 software (SPSS, Inc., Chicago, IL, USA). $P$ values $<0.05$ were considered significant.

Table 1 Primer sequences used for qRT-PCR analysis

\begin{tabular}{ll}
\hline Gene Name & Primer Sequence $\left(5^{\prime}->3^{\prime}\right)$ \\
\hline GAPDH & Foward CATCACTGCCACCCAGAAGACT \\
& Reverse GACACATTGGGGGTAGGAACAC \\
TNF-a & Foward CGAGTGACAAGCCTGTAGCCC \\
& Reverse GGGCAGCCTTGCCCTTGA \\
IL-6 & Foward AGTTGCCTTCTTGGGACTGA \\
& Reverse TTCTGCAAGTGCATCATCGT \\
\hline
\end{tabular}

\section{Results}

Characterization of major $\mathrm{PM}_{2.5}$ components

The concentrations of metal elements in the $\mathrm{PM}_{2.5}$ water extract, and the concentrations of PAHs in the $\mathrm{PM}_{2.5}$ organic extract were measured, and results are shown in Table 2. The composition of $\mathrm{PM}_{2.5}$ in the atmosphere is very complex due to many factors, such as the combustion source, industry pollution, climate, and season [31].

\section{Cell viability}

The viability of RAW264.7 cells exposed to $\mathrm{PM}_{2.5}$ water and organic extracts was evaluated using MTS assays. After 24 $\mathrm{h}$ exposure of RAW264.7 cells to a wide dose range of $\mathrm{PM}_{2.5}$ water and organic extracts from $12.5 \mu \mathrm{g} / \mathrm{mL}$ to $200 \mu \mathrm{g} / \mathrm{mL}$, the cell viability slightly decreased at the high doses $(100$ and $200 \mu \mathrm{g} / \mathrm{mL})$ as presented in Fig. 1 a, indicating that the toxicity of $\mathrm{PM}_{2.5}$ was not noticeable. Figure $1 \mathrm{~b}$ shows that BTE and Coelonin had no significant effects on the growth of RAW264.7 cells in the concentrations range of $0-20 \mu \mathrm{g} / \mathrm{mL}$, but significantly inhibitions were observed at $40 \mu \mathrm{g} / \mathrm{mL}$. Therefore, based on MTS assay and previous study [25], the concentrations of BTE used in the following experiments were $2.5,5,10$, and $20 \mu \mathrm{g} / \mathrm{mL}$, while the concentrations of Coelonin used in the following experiments were $1.25,2.5,5$, and $10 \mu \mathrm{g} / \mathrm{mL}$.

\section{Effective fraction of $B$. striata inhibits $\mathrm{PM}_{2.5}$-induced inflammatory cytokine expression in RAW264.7 cells} Inflammation played a major role in cell damage caused by $\mathrm{PM}_{2.5}$. In vitro, $\mathrm{PM}_{2.5}$ has been shown to induce inflammatory responses in various human and animal cells with time and dose dependent increases in gene expression [32], and it was found to result in increased macrophage infiltration and significantly upregulated TNF- $\alpha$ and IL-6 levels [33]. In the current study, TNF- $\alpha$ secretion by RAW264.7 cells exposed to $\mathrm{PM}_{2.5}$ extracts at $12.5,25,50,100$, and $200 \mu \mathrm{g} / \mathrm{mL}$ for 12 and $24 \mathrm{~h}$, were evaluated using ELISA. Figure 2 a indicates that TNF- $\alpha$ significantly increased in the cells treated by $\mathrm{PM}_{2.5}$ water extract in a concentration-dependent manner after comparing with the untreated cells. Figure $2 \mathrm{~b}$ illustrates that TNF- $\alpha$ secretion peaked in cells treated with $100 \mu \mathrm{g} / \mathrm{mL}$ $\mathrm{PM}_{2.5}$ organic extract. A significant injury was found in treated cells with $200 \mu \mathrm{g} / \mathrm{mL}$ WEP or $100 \mu \mathrm{g} / \mathrm{mL}$ OEP, and the dose was used in further experiments.

BTE and Coelonin were used to treat RAW264.7 cells and followed by exposure to $200 \mu \mathrm{g} / \mathrm{mL} \mathrm{PM}_{2.5}$ water extract or $100 \mu \mathrm{g} / \mathrm{mL} \mathrm{PM}_{2.5}$ organic extract. The IL-6, TNF- $\alpha$, and MCP-1 levels were elevated after exposure to $\mathrm{PM}_{2.5}$ extracts. The ability of BTE and Coelonin to inhibit TNF- $\alpha$, IL-6, and MCP-1 secretion induced by $\mathrm{PM}_{2.5}$ water or organic extract is illustrated in Fig. 3. In particular, the maximum declines in TNF- $\alpha$, IL-6, and MCP-1 (compared to the $\mathrm{PM}_{2.5}$ extract-only group) 
Table 2 Concentrations of elements in water and PAHs in organic extracts both at levels of $100 \mu \mathrm{g} / \mathrm{mL}$

\begin{tabular}{|c|c|c|c|}
\hline Content $(\mu \mathrm{g} / \mathrm{mL})$ & $\begin{array}{l}\text { Metal elements in } \\
\text { water extracts }\end{array}$ & Content $(\mu \mathrm{g} / \mathrm{mL})$ & PAHs in organic extracts \\
\hline $\begin{array}{l}\text { Sodium (Na) } \\
\text { Magnesium (Mg) } \\
\text { Phosphorous(P) } \\
\text { Kalium(K) } \\
\text { Lead (Pb) } \\
\text { Calcium (Ca) } \\
\text { Aluminium (Al) } \\
\text { Titanium (Ti) } \\
\text { Vanadium(V) } \\
\text { Chromium (Cr) } \\
\text { Manganese (Mn) } \\
\text { Iron (Fe) } \\
\text { Cobalt (Co) } \\
\text { Nickel (Ni) } \\
\text { Copper (Cu) } \\
\text { Zinc (Zn) } \\
\text { Arsenic (As) } \\
\text { Cadmium (Cd) } \\
\text { Barium (Ba) } \\
\text { Thallium (Tl) }\end{array}$ & $\begin{array}{l}5808.89 \\
965.45 \\
155.08 \\
2460.90 \\
9.20 \\
7136.49 \\
72.11 \\
0.96 \\
4.91 \\
3.54 \\
81.79 \\
102.02 \\
0.94 \\
4.23 \\
39.38 \\
1051.85 \\
31.87 \\
4.05 \\
40.04 \\
2.97\end{array}$ & $\begin{array}{l}\text { 2-Methylfluoranthene } \\
\text { 2-Methylphenanthrene } \\
\text { 1-Methylphenanthrene } \\
\text { 1-Methylpyrene } \\
\text { Perylene } \\
\text { Benzo(e)pyrene } \\
\text { Dibenzo(a, h)anthracene } \\
\text { Fluoranthene } \\
\text { Benzo(a)anthracene } \\
\text { Benzo(c)phenanthrene } \\
\text { Phenanthrene } \\
\text { Pyrene } \\
\text { Naphthalene } \\
\text { Fluorene } \\
\text { Chrysene } \\
\text { Benzo(b,j)fluoranthene } \\
\text { Benzo(a)pyrene } \\
\text { Benzo(k)fluoranthene } \\
\text { Acenaphthylene } \\
\text { Anthracene }\end{array}$ & $\begin{array}{l}0.16 \\
0.07 \\
0.09 \\
0.17 \\
0.26 \\
0.80 \\
0.13 \\
1.24 \\
0.62 \\
0.15 \\
0.48 \\
1.12 \\
0.05 \\
0.04 \\
1.04 \\
2.66 \\
0.99 \\
0.54 \\
0.03 \\
0.03\end{array}$ \\
\hline
\end{tabular}

occurred for $\mathrm{PM}_{2.5}$ water and organic extract-treated cells treated with $20 \mu \mathrm{g} / \mathrm{mL}$ BTE and $10 \mu \mathrm{g} / \mathrm{mL}$ Coelonin (the highest doses tested) (Fig. $3 \mathrm{~b}, \mathrm{c}$ ). For both of the $\mathrm{PM}_{2.5}$ water and organic extract-treated cells, the IL-6 and MCP-1 levels decreased in a dose-dependent manner when cells were treated with BTE or Coelonin (Fig. $3 \mathrm{e}-\mathrm{f})$. These results indicate that BTE or Coelonin pretreatment at a certain concentration range could reduce TNF- $\alpha$, IL- 6 and MCP-1 secretion in cell supernatants.

\section{EFB inhibits mRNA expression of inflammatory cytokines} Compared with the untreated RAW264.7 cells, there were obvious changes in TNF- $\alpha$ and IL- 6 mRNA expression after the exposure of RAW264.7 cells to $\mathrm{PM}_{2.5}$ water and organic extracts (Fig. 4). Regarding the $\mathrm{PM}_{2.5}$ water extract, TNF- $\alpha$ and IL- 6 mRNA expression was increased highest by $200 \mu \mathrm{g} / \mathrm{mL}$ (Fig. 4a and c). Regarding the $\mathrm{PM}_{2.5}$ organic extract, TNF- $\alpha$ and IL- 6 mRNA expression was increased highest by $100 \mu \mathrm{g} / \mathrm{mL}$ (Fig. 4b and d).

$\operatorname{BTE}(5,10$, and $20 \mu \mathrm{g} / \mathrm{mL})$ and Coelonin $(2.5,5$, and $10 \mu \mathrm{g} / \mathrm{mL}$ ) significantly decreased the TNF- $\alpha$ mRNA expression induced by $\mathrm{PM}_{2.5}$ water or organic extract (Fig. 5A, B). In addition, BTE $(2.5,5,10$, and $20 \mu \mathrm{g} / \mathrm{mL})$ and Coelonin $(1.25,2.5,5$, and $10 \mu \mathrm{g} / \mathrm{mL})$ significantly decreased the IL- 6 mRNA expression induced by $\mathrm{PM}_{2.5}$ organic extracts in a dose-dependent manner (Fig. 5D), and the results were the same for the $\mathrm{PM}_{2.5}$ water extract-treated cells, except that $2.5 \mu \mathrm{g} / \mathrm{mL}$ BTE had no effect (Fig. 5c). BTE or Coelonin reduced mRNA expression and protein synthesis to varying degrees. Briefly, qRT-PCR analysis showed that also performed to determine the protective effect of BTE or Coelonin in cultured mouse macrophage cell line RAW264.7 against $\mathrm{PM}_{2.5}$ water or organic extract treatment and the data were generally consistent with above results (Fig. $3 \mathrm{a}, \mathrm{b}$, $\mathrm{d}$ and $\mathrm{e})$.

EFB inhibited the NF-KB/MAPK pathway in $\mathrm{PM}_{2.5}$ extracttreated RAW264.7 cells

Based on previous literature [34], NF- $\mathrm{kB}$ pathway activation in RAW264.7 cells were assessed based on NF-кB and ІкB $\alpha$ phosphorylation. NF- $\mathrm{kB}$ is a transcription factor that has a

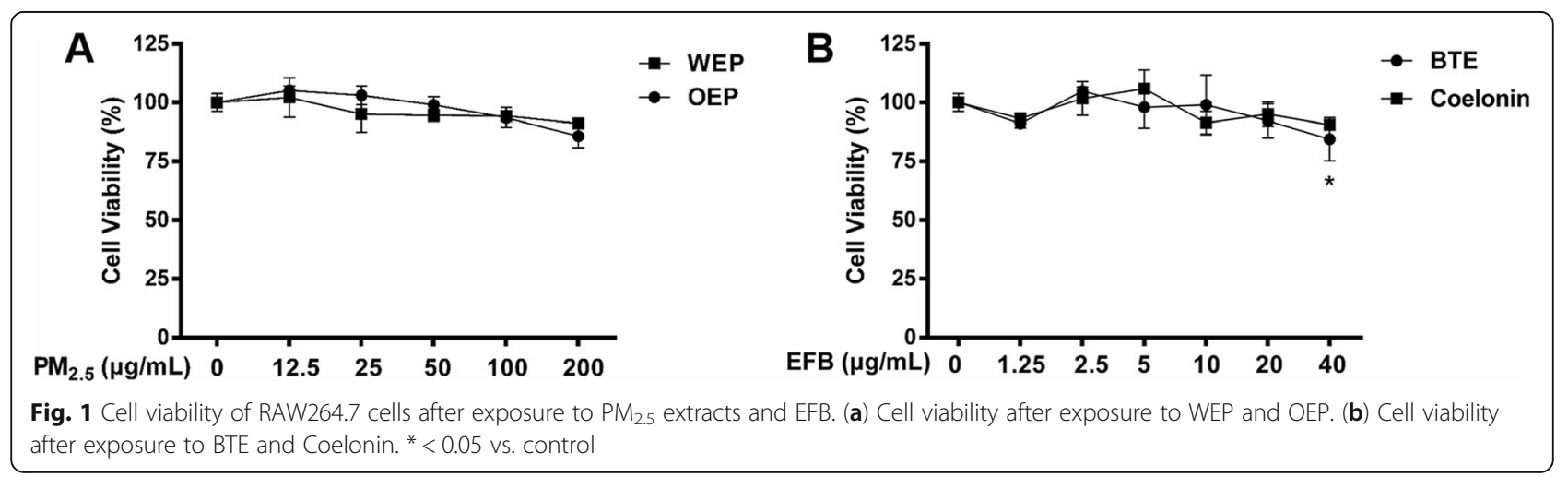




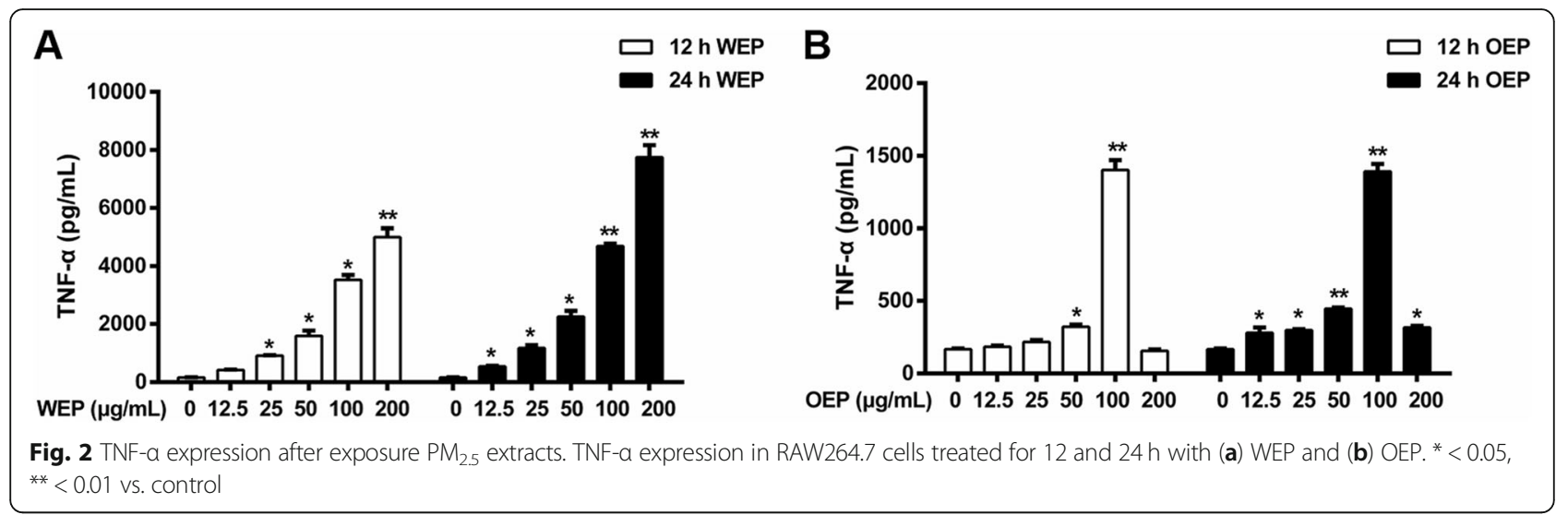

crucial role in inflammation, which can with MAPK cascade and provoke to tissue inflammatory damages [35]. In Figs. 6 and 7 , we propose a molecular mechanism for the inflammatory cytokine secretion induced by $\mathrm{PM}_{2.5}$ extracts. I $\mathrm{K} \mathrm{B} \alpha, \mathrm{NF}-$ кBp65, ERK, JNK, and p38 phosphorylation were significantly increased in $\mathrm{PM}_{2.5}$ water extract $(200 \mu \mathrm{g} / \mathrm{mL})$ and organic extract $(100 \mu \mathrm{g} / \mathrm{mL})$-treated cells compared with untreated cells, and expression level was related to $\mathrm{PM}_{2.5}$ extracts treatment time.

To clarify how $\mathrm{PM}_{2.5}$ extracts activated NF- $\mathrm{kB}$ and MAPK pathway, the mechanistic studies were conducted. BTE and Coelonin acted differently on the pathway activated by the $\mathrm{PM}_{2.5}$ water and organic extracts, but both significantly attenuated $\mathrm{PM}_{2.5}$ extracts induced phosphorylation. Specifically, the levels of NF-kB family protein were significantly elevated after the treatment of $\mathrm{PM}_{2.5}$ extracts, and decreased after the treatment of BTE and Coelonin at some tested concentrations (Fig. 8). Moreover, $\mathrm{PM}_{2.5}$ water or organic extract induced phosphorylation of MAPK family protein ERK, JNK and p38 level which was notably attenuated by BTE or Coelonin pretreatment (Fig. 9). In a word, these results suggest that BTE or Coelonin significantly alleviated the activation of MAPK cascade, and particularly mitigated the NF- $\kappa B$ binding through prevention of $\mathrm{PM}_{2.5}$ extracts induced

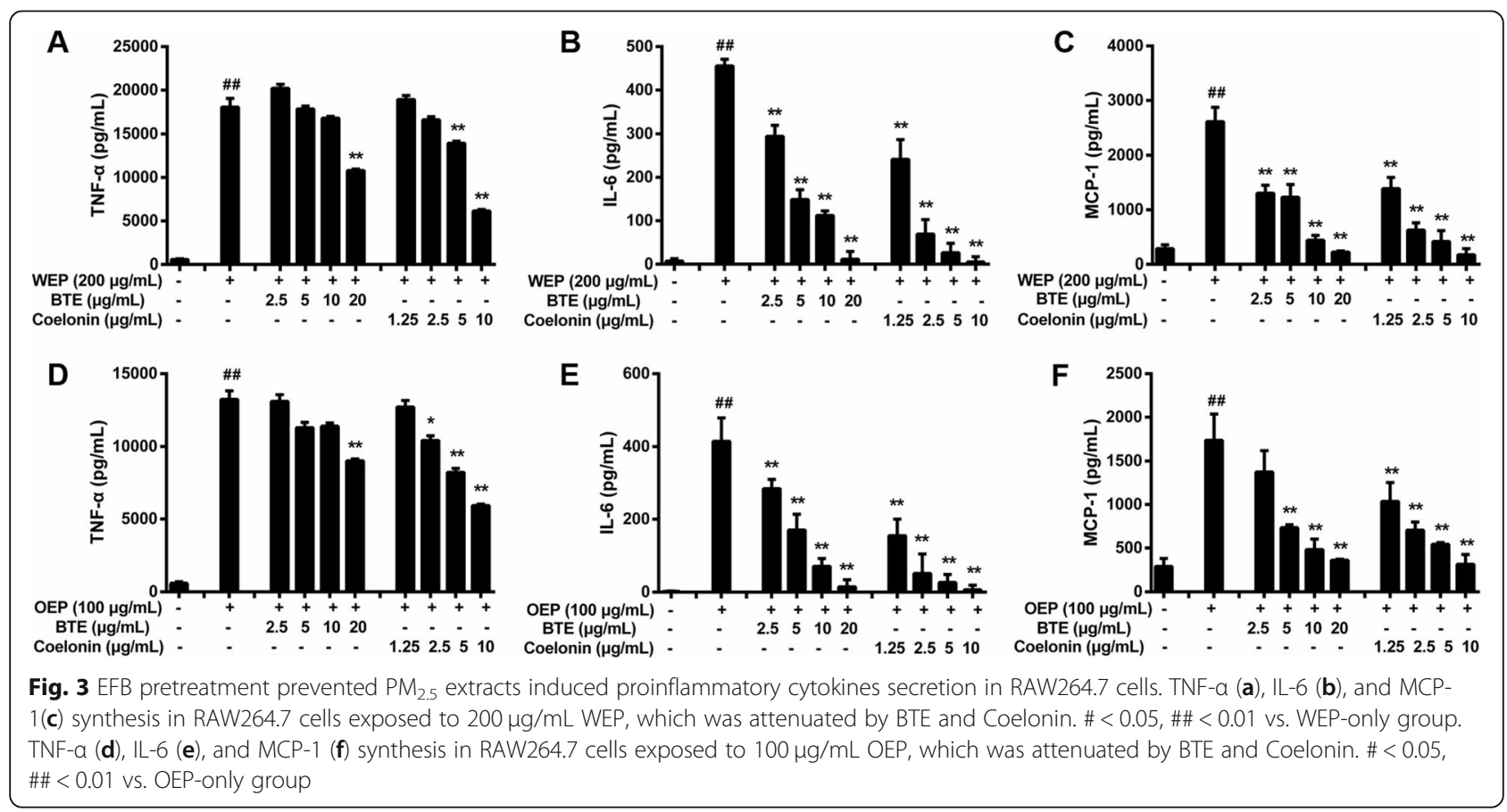



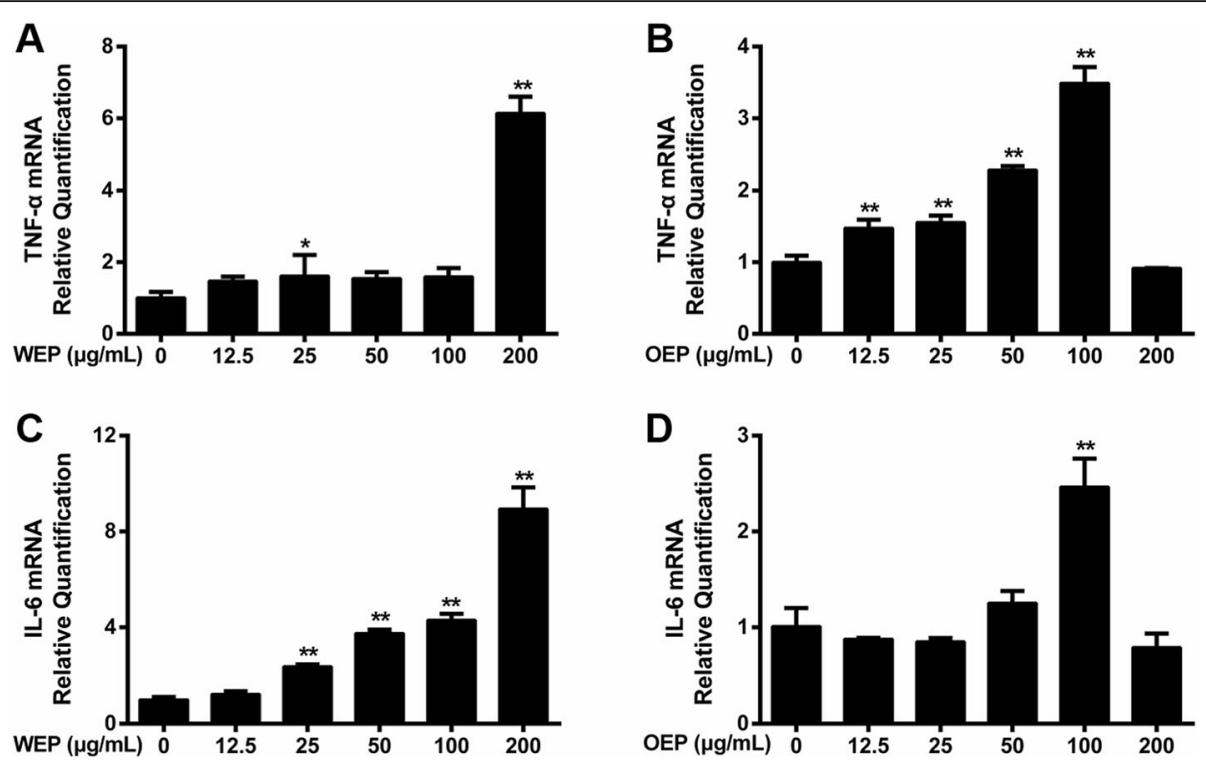

Fig. 4 Effects of $\mathrm{PM}_{2.5}$ extracts on the mRNA expression of inflammatory cytokines in RAW264.7 cells. After 18 h, mRNA expression of (a) TNF-a and (b) IL-6 in WEP $(200 \mu \mathrm{g} / \mathrm{mL})$-treated RAW264.7 cells and of (c) TNF-a and (d) IL-6 in OEP $(100 \mu \mathrm{g} / \mathrm{mL})$-treated RAW264.7 cells. ${ }^{*}<0.05$, ${ }^{* *}<0.01$ vs. control.

I $\mathrm{B} \alpha$ and NF-kBp65 phosphorylation as well as degradation.

\section{Discussion}

Innate immunity is classically viewed as a first line of resistance against pathogens [36]. Macrophages are effector cells of the innate immune system that phagocytose bacteria and secrete both pro-inflammatory and antimicrobial mediators [37]. Exposure to $\mathrm{PM}_{2.5}$ activates macrophages, enabling them to initiate defense against, and phagocytosis of, $\mathrm{PM}_{2.5}$, which activates a series of transcription factors and promotes cytokine production to inhibit the toxicity of $\mathrm{PM}_{2.5}$; however, an excessive inflammatory response can induce cell damage and a systemic inflammatory response [38-40]. IL-6, mainly
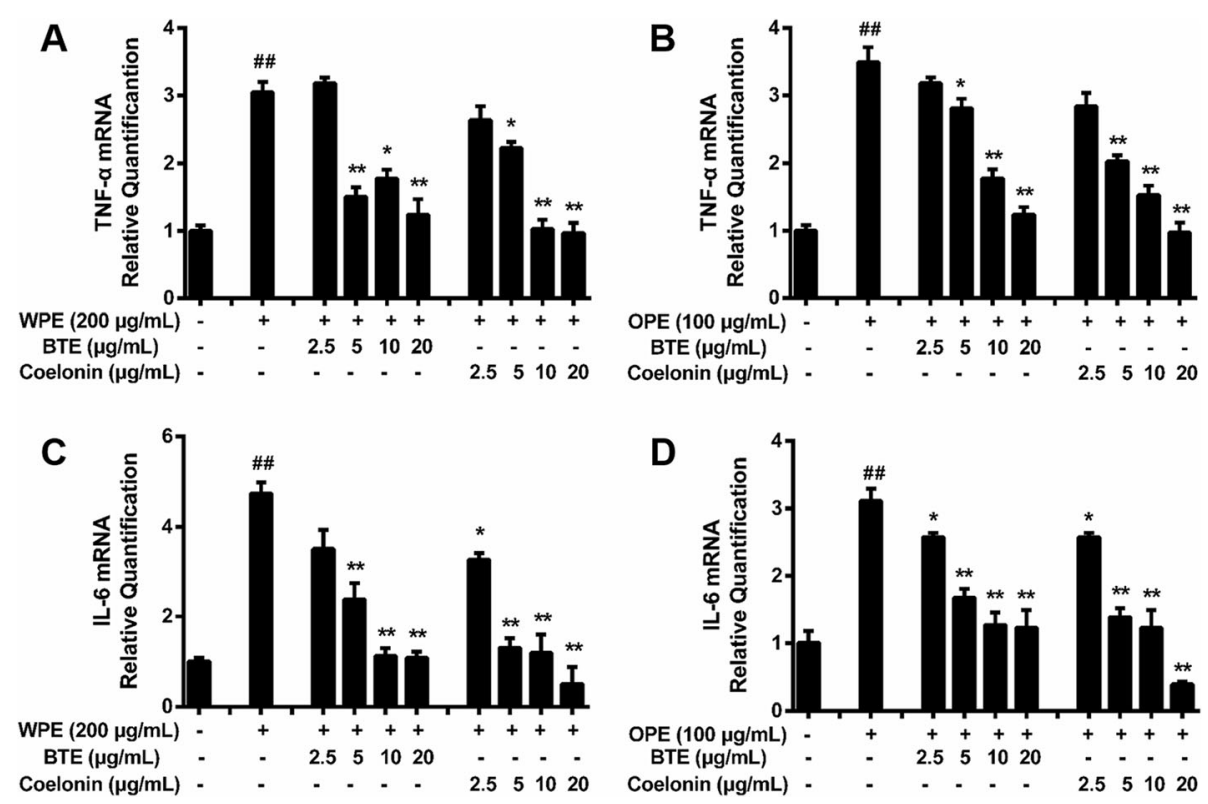

Fig. 5 EFB inhibited the effects of PM 2.5 extracts on the mRNA expression of inflammatory cytokines.mRNA expression of (a) TNF-a and (b) IL-6 in WEP $(200 \mu \mathrm{g} / \mathrm{mL})$-treated RAW264.7 cells and of (c) TNF-a and (d) IL-6 in OEP $(100 \mu \mathrm{g} / \mathrm{mL})$-treated RAW264.7 cells, which was attenuated by BTE and Coelonin. \#<0.05, \#\#<0.01 vs. control. ${ }^{*}<0.05,{ }^{* *}<0.01$ vs. model $\left(\mathrm{PM}_{2.5}\right.$ extract-only group) 


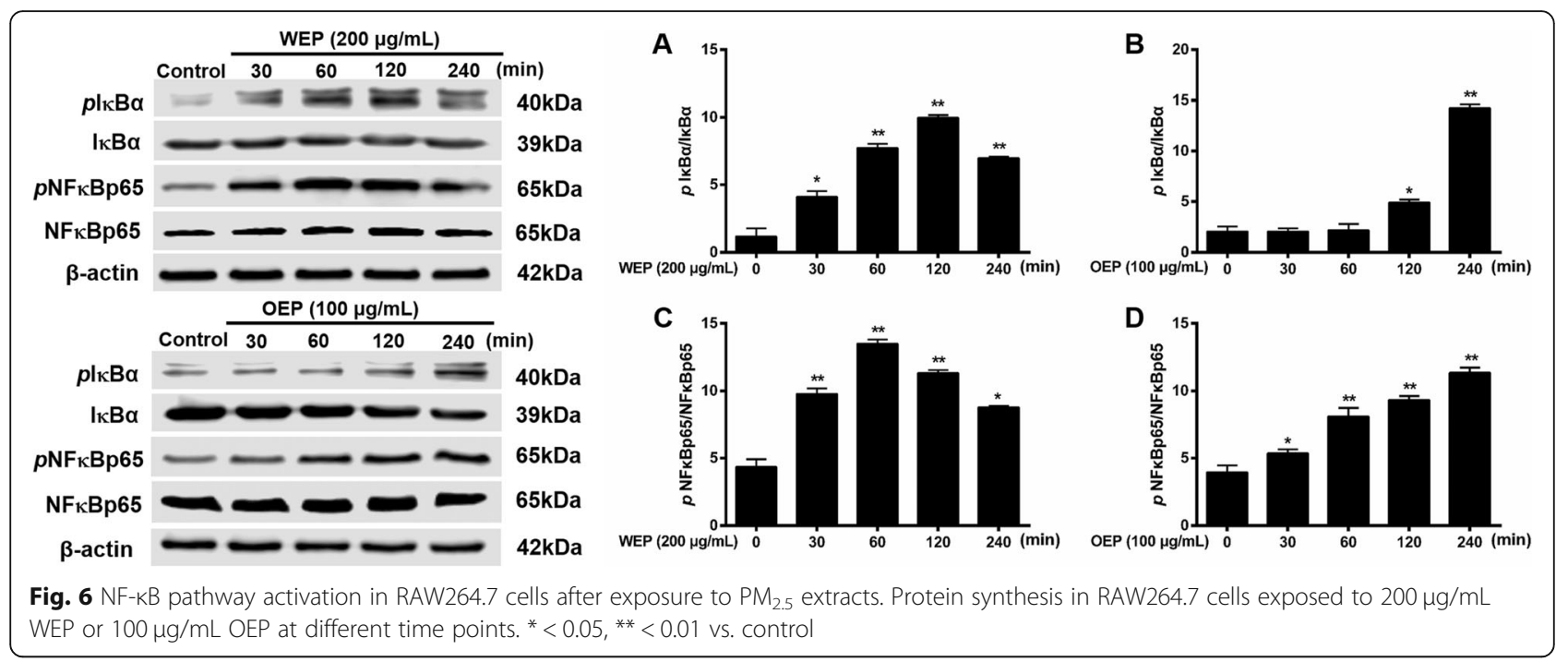

produced by alveolar epithelial cells, regulates the immune response, participates in inflammatory reactions and antiinfection defense, and is one of the main indicators of early inflammation [41, 42]. TNF- $\alpha$ is a cytokine secreted after stimulation, and it can promote the secretion of cytokines such as IL-6 and IL-8 in cooperation with IL-1, act on alveolar epithelial cells and then further induce increased expression inflammatory factors to initiate an inflammatory response in the lungs $[43,44]$.

The inflammatory response induced by $\mathrm{PM}_{2.5}$ is related to the NF- $\kappa B$ signaling pathway, involving $I \kappa B \alpha$ and $\operatorname{IKK} \beta$, and upregulation of this pathway increases the production of inflammatory cytokines $[45,46]$. As a nuclear transcription factor, NF- $\mathrm{kB}$ is a major signaling protein in inflammatory diseases, and it plays an important role in inflammation, immunity, cell proliferation, and differentiation [47]. The present study showed that I $\mathrm{KB} \alpha$ and NF- $\mathrm{KB}$ were rapidly elevated in $\mathrm{PM}_{2.5}$ extracttreated RAW264.7 cells. BTE and Coelonin attenuated this increased. More and more studies $[48,49]$ have shown that oxidative stress in tissue and nerve injuryrelated inflammation is caused by the NF- $\mathrm{KB}$ signaling pathway, and the resultant inflammatory factors accelerate the development of systemic diseases, promoting more inflammation and accelerating injury [50]. The cytokine secretion caused by oxidative stress, especially MCP-1 (also known as CCL2P), plays an important role in monocyte recruitment to inflammatory sites. It was previously found that MCP- 1 and IL- 6 levels in mice exposed to $\mathrm{PM}_{2.5}$ increased significantly, indicating that MCP-1 and IL-6 are involved in the inflammatory response to $\mathrm{PM}_{2.5}$ [51]. It has also been reported that lung

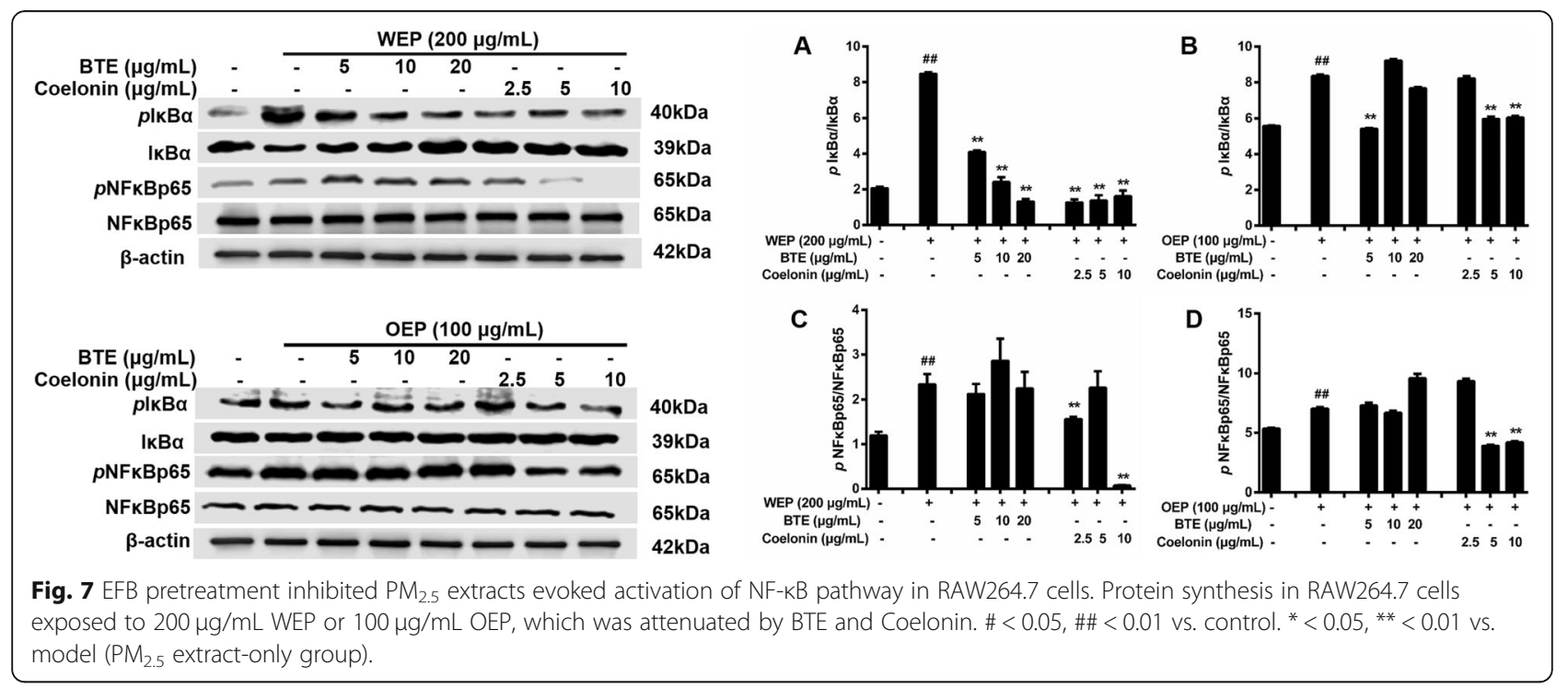



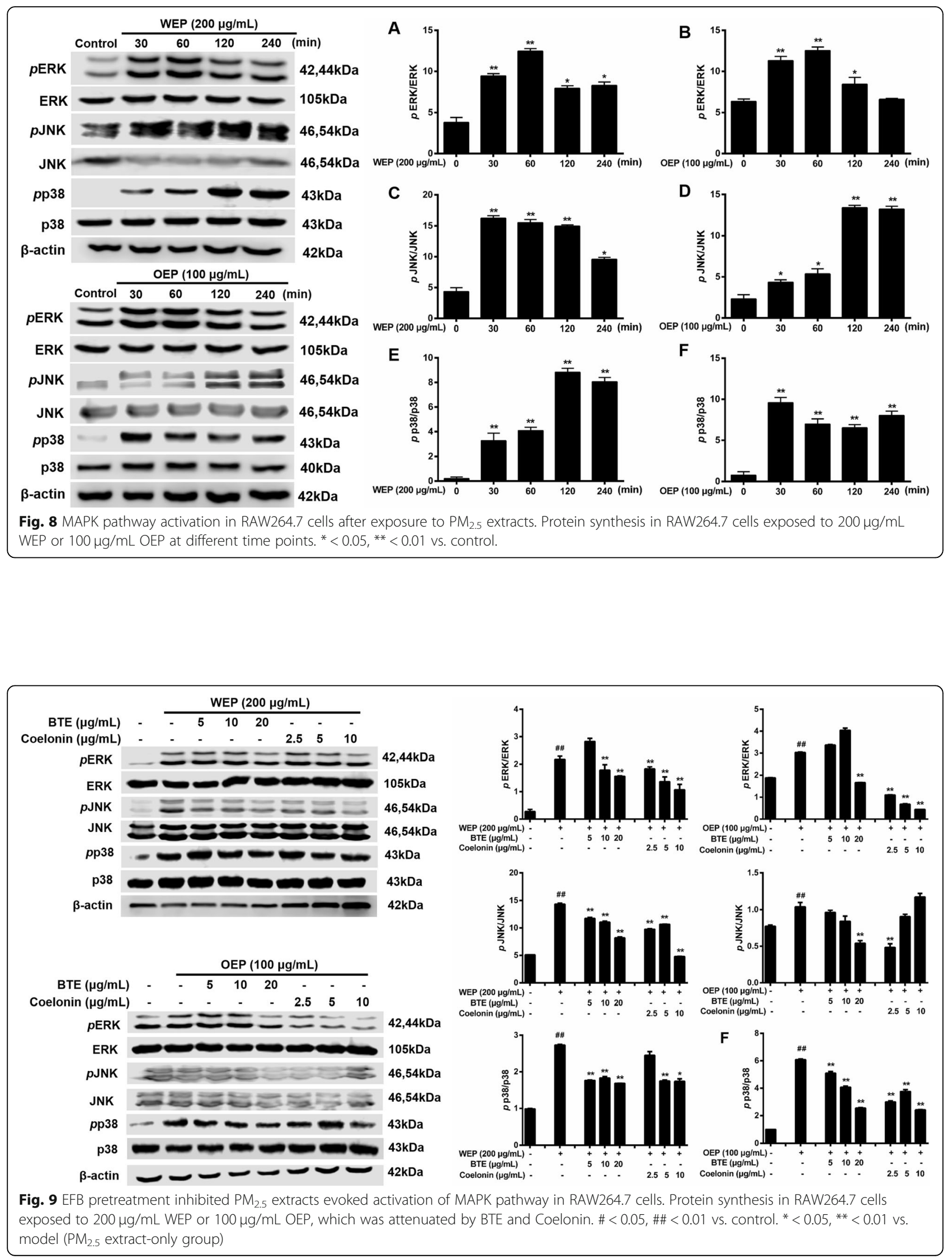


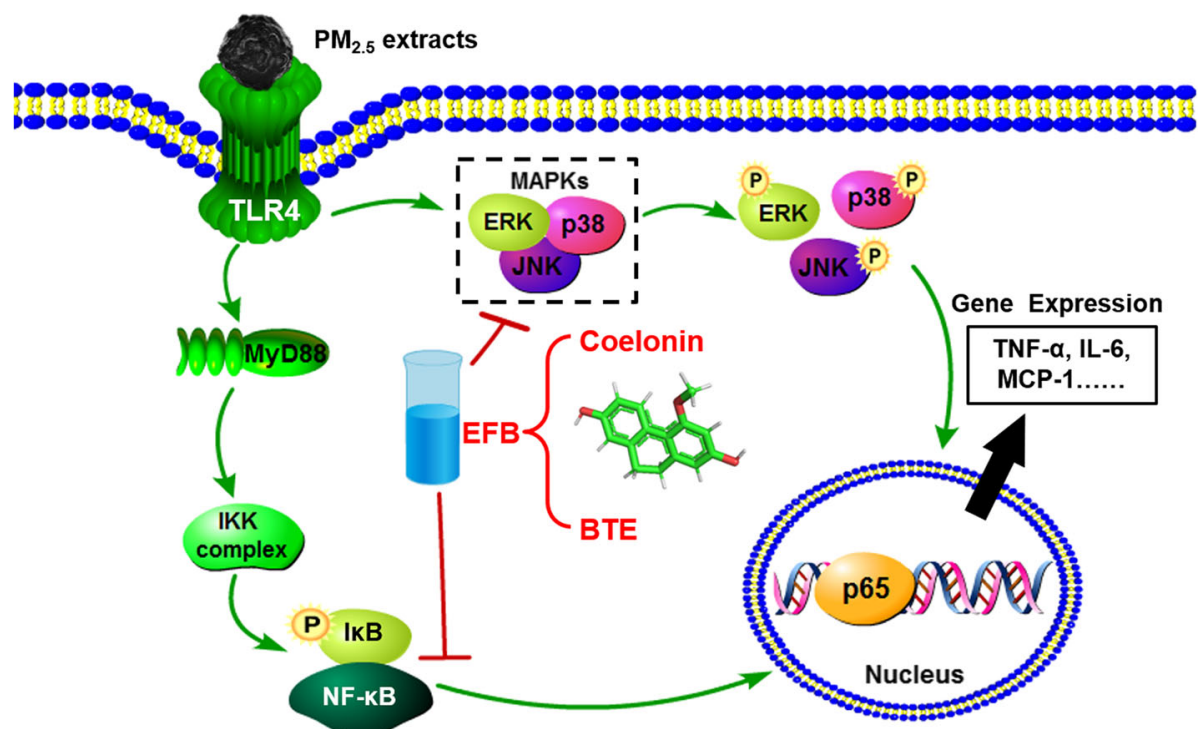

Fig. 10 Proposed mechanism of EFB in inhibiting PM 2.5 extracts activation of NF-KB/MAPK signaling pathways in RAW264.7 cells

tissue injury induced by $\mathrm{PM}_{2.5}$ is related to the activation of the p38/NF- $\mathrm{BB}$ signaling pathway, while oxidative stress induced by $\mathrm{PM}_{2.5}$ in human vascular endothelial cells increases ICAM-1 and VCAM-1 expression through the ERK/Akt/NF- $\mathrm{kB}$ signaling pathway [52].

Macrophages can phagocytose $\mathrm{PM}_{2.5}$ and other exogenous substances, resulting in increased reactive oxygen species (ROS) levels, mediated by NADPH on the cell membrane [53]. However, excessive ROS production can increase the permeability of the lysosomal membrane, decreasing lysosomal stability and causing cathep$\sin$ B and D release [54]. Cathepsin B can act on mitochondria through Bid and caspase-2, while cathepsin $\mathrm{D}$ can act on mitochondria through Bax, resulting in an increase in membrane permeability, the release of cytochrome $\mathrm{C}$, and further inducing the mitochondrial release of ROS [55]. The ROS-MAPK/Akt signaling pathway can improve the airway microenvironment by decreasing the Akt and MAPK phosphorylation induced by ROS and by inhibiting the secretion of the chemokines MCP-1 and IL-8, and intercellular adhesion molecule-1 (ICAM-1) [56].

B. striata, a well-known traditional Chinese herb, has been widely used to treat hematemesis, ulcers and skin chapping. Previous studies in our laboratory showed that the chloroform and ethyl acetate extract further separated from the $B$. striata ethanol extract has strong antifree radical activity, while the chloroform extract also has strong tyrosinase inhibition activity and anti-tumor activity [21] and the chloroform, ethyl acetate, and nbutanol extracts have strong antibacterial activity [19]. It is inferred that $B$. striata and its extracts can interfere with lung injury induced by $\mathrm{PM}_{2.5}$. In this study, we explore the effects of BTE or Coelonin on $\mathrm{PM}_{2.5}$ water extract or organic extract induced cellular inflammatory injury in cultured the mouse macrophage cell line RAW264.7 and further to investigate the molecular mechanism of anti-inflammatory. An elevated level of proinflammatory cytokines such as TNF- $\alpha$ and IL-6 suggests the establishment of local inflammatory response. Our results showed that the increased level of TNF- $\alpha$, IL-6 and MCP-1 expression in RAW264.7 cells were attributable to the damaging effects of $\mathrm{PM}_{2.5}$ water or organic extract (Figs. 2, 3 and 4). Pretreatment of BTE or Coelonin reduced the secretion of inflammatory cytokines by $\mathrm{PM}_{2.5}$ water and organic extract-treated cells, indicating that the components of $\mathrm{PM}_{2.5}$ water and organic extracts induce inflammatory cytokine secretion independently of NF- $\mathrm{kB}$, MAPK pathway, and inflammasomes (Fig. 3). The results showed that EFB reduced the mRNA expression of IL- 6 and TNF- $\alpha$, deactivated the NF- $\mathrm{kB} / \mathrm{MAPK}$ signaling pathways (Fig. 5). Next, we examined EFB decreased expression levels of $\operatorname{I\kappa }_{\kappa} \alpha$ and NF-kBp65 phosphorylation in $\mathrm{PM}_{2.5}$ extracts induced macrophages. Furthermore, ERK, JNK, and p38 protein phosphorylation levels were assessed by Western blotting (Figs. 8 and 9). Results showed that EFB specifically inhibited the inflammatory response through regulation of NF-kB/MAPK signaling (Fig. 10). These results suggest that Coelonin may be one of the main antiinflammatory active components of $B$. striata ethanol extract which were in accordance with previously published evidences [25]. Its protective effect on RAW264.7 cells damaged by $\mathrm{PM}_{2.5}$ may be related to the inhibition of NF- $\mathrm{kB}$ activation and MAPK signals. The secretion of inflammatory cytokine was effectively suppressed by 
BTE and Coelonin, suggesting that BTE and Coelonin can potentially become effective components of antiinflammatory medicine. Their specific mechanisms for anti-inflammatory effects are to be further investigated.

\section{Conclusions}

In summary, the present study indicates that $\mathrm{PM}_{2.5}$ extracts can induce inflammatory responses and BTE and Coelonin may protect mouse macrophage through antiinflammatory, possibly via the involvement of NF- $\mathrm{kB}$ / MAPK signaling pathways. Based on the protective effects of BTE and Coelonin observed in pretreated cells, the regulation of BTE and Coelonin can be a fascinating approach to prevent/treat macrophage injury in inflammation response. B. striata, a well-known traditional Chinese medicine, alleviates $\mathrm{PM}_{2.5}$ extract-induced pulmonary inflammation. BTE and Coelonin inhibited the expression of inflammatory cytokines in RAW264.7 cells. Thus, B. striata may be useful as a pharmacological agent to protect against $\mathrm{PM}_{2.5}$-induced inflammatory disease.

\section{Supplementary information}

Supplementary information accompanies this paper at https://doi.org/10. 1186/s12906-019-2790-3

Additional file 1. Isolation, purification and identification of Coelonin.

\section{Abbreviations}

BTE: Bletilla striata total ethanol-extract; Coelonin: 2,7-dihydroxy-4-methoxy9,10-dihydrophenanthrene; DMEM: Dulbecco's Modified Eagle Medium; DMSO: Dimethyl sulfoxide; EFB: The effective fraction of Bletilla striata; ELISA: Enzyme-linked immunosorbent assay; ERK: Extracellular signalregulated kinase; HPLC: High-performance liquid chromatography; IL6: Interleukin-6; JNK: c-Jun N-terminal kinase; MAPK: Mitogen-activated protein kinase; MCP-1: Monocyte chemoattractant protein - 1; MTS: (3-(4,5dimethylthiazol-2-yl)-5-(3-carboxymethoxyphenyl)-2-(4-sulfophenyl)-2Htetrazolium); NF-KB: nuclear factor-kappa B; OEP: Organic extracts of PM 2.5 i TNF-a: tumor necrosis factor-a; WEP: Water extracts of $\mathrm{PM}_{2.5}$

\section{Acknowledgements}

The authors are grateful to Dr. Ran Li (College of Basic Medical Sciences, Zhejiang Chinese Medical University) for her help in cell technology.

\section{Authors' contributions}

ZSD and LXJ conceived the study. YYZ and QFL performed the experiments, analyzed the data and wrote the manuscript. SXT performed the data analysis. LXJ, FSJ and MYL contributed to methodology. BQZ amended the manuscript. ZSD acquired funding, contributed to resources, and supervised the study.

\section{Funding}

This work was supported by grants from the National Natural Scientific Foundation, China (Grant Numbers 81673672). The funding body had no role in the design of the study; collection, analysis, and interpretation of data; and in writing the manuscript.

\section{Availability of data and materials}

The datasets used and analyzed during this study would be available upon request from the corresponding author.

Ethics approval and consent to participate Not applicable.
Consent for publication

Not applicable.

\section{Competing interests}

The authors declare that they have no competing interests.

\section{Author details}

${ }^{1}$ College of Life Science, Zhejiang Chinese Medical University, Zhejiang 310053, Hangzhou, China. ${ }^{2}$ College of Medical Technology, Zhejiang Chinese Medical University, Zhejiang 310053, Hangzhou, China. ${ }^{3}$ Academy of Chinese Medical Sciences, Zhejiang Chinese Medical University, Hangzhou 310053, China.

Received: 25 September 2019 Accepted: 8 December 2019

Published online: 16 December 2019

\section{References}

1. Li N, Hao M, Phalen RF, Hinds WC, Nel AE. Particulate air pollutants and asthma. A paradigm for the role of oxidative stress in PM-induced adverse health effects. Clin Immunol. 2003;109:250-65.

2. Hertz-Picciotto I, Baker RJ, Yap PS, Dostál M, Joad JP, Lipsett M, Greenfield T, Herr CE, Benes I, Shumway RH, Pinkerton KE, Srám R. Early childhood lower respiratory illness and air pollution. Environ Health Perspect. 2007:115:1510-8.

3. Sint T, Donohue JF, Ghio AJ. Ambient air pollution particles and the acute exacerbation of chronic obstructive pulmonary disease. Inhal Toxicol. 2008; 20:25-9.

4. Lin CH, Huang CC, Wang TW, Wang YJ, Lin PH. Disparity in the induction of glutathione depletion, ROS formation, poly (ADP-ribose) polymerase-1 activation, and apoptosis by quinonoid derivatives of naphthalene in human cultured cells. Chem Biol Interact. 2007:165:200-10.

5. Møller P, Danielsen PH, Karottki DG, Jantzen K, Roursgaard M, Klingberg H, Jensen DM, Christophersen DV, Hemmingsen JG, Cao Y, Loft S. Oxidative stress and inflammation generated DNA damage by exposure to air pollution particles. Mutat Res Rev Mutat Res. 2014;762:133-66.

6. Xu Z, Li Z, Liao Z, Gao S, Hua L, Ye X, Wang Y, Jiang S, Wang N, Zhou D, Deng $X$. PM2.5 induced pulmonary fibrosis in vivo and in vitro. Ecotoxicol Environ Saf. 2019;171:112-121.

7. Song C, He L, Zhang J, Ma H, Yuan X, Hu G, Tao L, Zhang J, Meng J. Fluorofenidone attenuates pulmonary inflammation and fibrosis via inhibiting the activation of NALP3 inflammasome and IL-1ß/IL-1R1/MyD88/ NF-KB pathway. J Cell Mol Med. 2016;20:2064-77.

8. Jin M, Suh SJ, Yang JH, Lu Y, Kim SJ, Kwon S, Jo TH, Kim JW, Park YI, Ahn GW, Lee CK, Kim CH, Son JK, Son KH, Chang HW. Anti-inflammatory activity of bark of Dioscorea batatas DECNE through the inhibition of iNOS and COX-2 expressions in RAW264.7 cells via NF-kB and ERK1/2 inactivation. Food Chem. Toxicol. 2010;48:3073-9.

9. Saklatvala J. Inflammatory signaling in cartilage: MAPK and NF-kappaB pathways in chondrocytes and the use of inhibitors for research into pathogenesis and therapy of osteoarthritis. Curr Drug Targets. 2007:8:305-13.

10. Nemmar A, Holme JA, Rosas I, Schwarze PE, Alfaro-Moreno E. Recent advances in particulate matter and nanoparticle toxicology: a review of the in vivo and in vitro studies. Biomed Res Int. 2013:2013:279371.

11. Fernando IPS, Jayawardena TU, Sanjeewa KKA, Wang L, Jeon YJ, Lee WW. Anti-inflammatory potential of alginic acid from Sargassum horneri against urban aerosol-induced inflammatory responses in keratinocytes and macrophages. Ecotoxicol Environ Saf. 2018;160:24-31.

12. Yu Q, Nie SP, Wang JQ, Yin PF, Li WJ, Xie MY. Polysaccharide from Ganoderma atrum induces tumor necrosis factor-a secretion via phosphoinositide 3-kinase/Akt, mitogen-activated protein kinase and nuclear factor-KB signaling pathways in RAW264.7 cells. Int Immunopharmacol. 2012;14:362-8.

13. Chen $Z$, Cheng L, He Y, Wei X. Extraction, characterization, utilization as wound dressing and drug delivery of Bletilla striata polysaccharide: a review. Int J Biol Macromol. 2018;120:2076-85.

14. Zhao G, Li K, Chen J, Li L. Protective effect of extract of Bletilla striata on isoflurane induced neuronal injury by altering PI3K/Akt pathway. Transl Neurosci. 2018:9:183-9.

15. Luo L, Liu Y, Cai X, Wang Y, Xue J, Zhang J, Yang F. Bletilla striata polysaccharides ameliorates lipopolysaccharide-induced injury in intestinal epithelial cells. Saudi J Gastroenterol. 2019;25:302-8. 
16. He X, Wang X, Fang J, Zhao Z, Huang L, Guo H, Zheng X. Bletilla striata: medicinal uses, phytochemistry and pharmacological activities. J Ethnopharmacol. 2017;195:20-38.

17. Zhang C, Gao F, Gan S, He Y, Chen Z, Liu X, Fu C, Qu Y, Zhang J. Chemical characterization and gastroprotective effect of an isolated polysaccharide fraction from Bletilla striata against ethanol-induced acute gastric ulcer. Food Chem Toxicol. 2019;131:110539.

18. Qian CD, Jiang FS, Yu HS, Shen Y, Fu YH, Cheng DQ, Gan LS, Ding ZS. Antibacterial Biphenanthrenes from the fibrous roots of Bletilla striata. J Nat Prod. 2015;78:939-4378.

19. Guo JJ, Dai BL, Chen NP, Jin LX, Jiang FS, Ding ZS, Qian CD. The antiStaphylococcus aureus activity of the phenanthrene fraction from fibrous roots of Bletilla striata. BMC Complement Altern Med. 2016;16:491.

20. Shi Y, Zhang B, Lu YY, Qian CD, Feng Y, FL, Ding ZS, Cheng DQ Antiviral activity of phenanthrenes from the medicinal plant Bletilla striata against influenza A virus BMC Complement Altern Med 2017;17:273.

21. Jiang FS, Li WP, Huang YF, Chen YT, Jin B, Chen NP, Ding ZS, Ding XH. Antioxidant, antityrosinase and antitumor activity comparison: the potential utilization of fibrous root part of Bletilla striata (Thunb.) Reichb.F. PLoS One. https://doi.org/10.1371/journal.pone.0058004.

22. Xu P, Yao Y, Zhou J. Particulate matter with a diameter of $\leq 2.5 \mu \mathrm{m}$ induces and enhances bleomycin-induced pulmonary fibrosis by stimulating endoplasmic reticulum stress in rat. Biochem Cell Biol. 2019:97:357-63.

23. Liu S, Zhang W, Zhang F, Roepstorff P, Yang FQ, Lu ZB, Ding WJ. TMT-Based Quantitative Proteomics Analysis Reveals Airborne PM2.5-Induced Pulmonary Fibrosis. Int J Environ Res Public Health. 2018;16. pii: E98.

24. Deng YZ, Jin LX, Gao CX, Qian CD, Jiang FS, Ding ZS, Li MY. Research on the anti-pulmonary fibrosis effect of the small molecule components of Bletilla striata in rat silicosis model. J Chin Med Mater. 2016;39:2615-9.

25. Jiang FS, Li MY, Wang HY, Ding B, Zhang CC, Ding ZS, Yu XB, Lv GY. Coelonin, an anti-inflammation active component of Bletilla striata and its potential mechanism. Int J Mol Sci. 2019;20.

26. Li HY, Shi ZZ, Shu LF, Wang J, Li MY, Ding ZS, Jiang FS. Research on the anti-pulmonary fibrosis effect of the Bletilla striata polysaccharide in rat silicosis model. J. Chin. Med. Mater. 2016;39:1638-42.

27. Luo L, Liu YQ, Cai X, Wang Y, Xue J, Zhang J, Yang F. Bletilla striata polysaccharides ameliorates lipopolysaccharide-induced injury in intestinal epithelial cells. Saudi J Gastroenterol. 2019;25:302-8.

28. Long Y, Wang W, Wang Y, Du T, Shen WP, Tang HL, Wang Y, Yin HP. Bletilla striata polysaccharide inhibits angiotensin II-induced ROS and inflammation via NOX4 and TLR2 pathways. Int J Biol Macromol. 2016;89:376-88.

29. Luo L, Zhou Z, Xue J, Wang Y, Zhang J, Cai X, Liu Y, Yang F. Bletilla striata polysaccharide has a protective effect on intestinal epithelial barrier disruption in TAA-induced cirrhotic rats. Exp Ther Med. 2018;16:1715-22.

30. Xu FF, Qiu XH, Hu XY, Shang Y, Michal P, Fang YH, Wang JX, Yinon R, Zhu T. Effects on IL-1 $\beta$ signaling activation induced by water and organic extracts of fine particulate matter $\left(\mathrm{PM}_{25}\right)$ in vitro. Environ. Pollut. 2018;237:592-600.

31. Bocchi C, Bazzini C, Fontana F, Pinto G, Martino A, Cassoni F. Characterization of urban aerosol: seasonal variation of genotoxicity of the water-soluble portion of $\mathrm{PM}_{2.5}$ and $\mathrm{PM}_{1}$. Mutat. Res. 2019;841:23-30.

32. Choi H, Lee W, Kim E, Ku SK, Bae JS. Inhibitory effects of collismycin C and pyrisulfoxin a on particulate matter induced pulmonary injury. Phytomedicine. 2019;62:152939.

33. Shi QW, Zhao L, Xu CM, Zhang LF, Zhao H. High Molecular Weight Hyaluronan Suppresses Macrophage M1 Polarization and Enhances IL-10 Production in $\mathrm{PM}_{2.5}$-Induced Lung Inflammation. Molecules. 2019;24:1766.

34. Su YS, Xiong SZ, Lan HW, Xu LJ, Wei X. Molecular mechanism underlying anti-inflammatory activities of lirioresinol B dimethyl ether through suppression of NF-KB and MAPK signaling in in vitro and in vivo models. Int Immunopharmacol. 2019;73:321-32.

35. Akanda MR, Park BY. Involvement of MAPK/NF-KB signal transduction pathways: Camellia japonica mitigates inflammation and gastric ulcer. Biomed Pharmacother. 2017;95:1139-46.

36. Locati M, Mantovani A, Sica A. Macrophage activation and polarization as an adaptive component of innate immunity. Adv Immunol. 2013;120:163-84.

37. Hirayama D, lida T, Nakase $H$. The Phagocytic Function of MacrophageEnforcing Innate Immunity and Tissue Homeostasis. Int J Mol Sci. 2017;19. pii: E92.

38. Brunekreef B, Holgate ST. Air pollution and health. Lancet. 2002;360:1233-42.

39. Steenhof M, Gosens I, Strak M, Godri KJ, Hoek G, Cassee FR, Mudway IS, Kelly FJ, Harrison RM, Lebret E, Brunekreef B, Janssen NA, Pieters RH. In vitro toxicity of particulate matter (PM) collected at different sites in the Netherlands is associated with PM composition, size fraction and oxidative potentialthe RAPTES project. Part Fibre Toxicol. 2011;8:268.

40. Chinetti-Gbaquidi G, Baron M, Bouhlel MA, Vanhoutte J, Copin C, Sebti Y, Derudas B, Mayi T, Bories G, Tailleux A, Haulon S, Zawadzki C, Jude B, Staels B. Human atherosclerotic plaque alternative macrophages display low cholesterol handling but high phagocytosis because of distinct activities of the PPAR gamma and LXR alpha pathways. Circ Res. 2011;108:985-95.

41. Thurston LM, Siggins K, Mileham AJ, Watson PF, Holt WV. Identification of amplified restriction fragment lenghth polymorphis markers linked to genes controlling boar sperm viability following cryopreservation. Biol Reprod. 2002;66:545-54.

42. Thomson EM, Breznan D, Karthikeyan S, MacKinnon-Roy C, Charland JP, Dabek-Zlotorzynska E, Celo V, Kumarathasan P, Brook JR, Vincent R. Effects of atmospheric fine particle pollutant $\mathrm{PM}_{2.5}$ concentration on inflammatory factors in pulmonary epithelial cells. Part Fibre Toxicol. 2015;12:24.

43. Lee JW, Ryu HW, Lee SU, Kim MG, Kwon OK, Kim MO, Oh TK, Lee JK, Kim TY, Lee SW, Choi S, Li WY, Ahn KS, Oh SR. Pistacia weinmannifolia ameliorates cigarette smoke and lipopolysaccharide-induced pulmonary inflammation by inhibiting interleukin-8 production and NF-kB activation. Int J Mol Med. 2019:44:949-59.

44. Wang FY, Liang ZY, Yang YQ, Zhou LQ, Guan LL, Wu WL, Jiang M, Shi WJ, Deng KM, Chen JH, Chen RC. Reproducibility of fluid-phase measurements in PBS-treated sputum supernatant of healthy and stable COPD subjects. Int J Chron Obstruct Pulmon Dis. 2019;14:835-52.

45. Song L, Li D, Li XP, Ma LJ, Bai XX, Wen M, Zhang XF, Chen D, Peng LP. Exposure to $\mathrm{PM}_{2.5}$ induces aberrant activation of NF-KB in human airway epithelial cells by downregulating miR-331 expression. Environ Toxicol Pharmacol. 2017;50:192-9.

46. Ying ZK, Xu XH, Bai YT, Zhong JX, Chen MJ, Liang YJ, Zhao JZ, Liu DY, Masako M, Sun QH, Catherine S, Robert DB, Jack RH, Sanjay R. Long-term exposure to concentrated ambient $\mathrm{PM}_{2.5}$ increases mouse blood pressure through abnormal activation of the sympathetic nervous system: a role for hypothalamic inflammation. Environ Health Perspect. 2014;122:79-86.

47. Sama P, Long TC, Hester S, Tajuba J, Parker J, Chen LC, Veronesi B. The cellular and genomic response of an immortalized microglia cell line (BV2) to concentrated ambient particulate matter. Inhal Toxicol. 2007;19:1079-87.

48. Nam HY, Choi BH, Lee JY, Lee SG, Kim YH, Lee KH, Yoon HK, Song JS, Kim HJ, Lim Y. The role of nitric oxide in the particulate matter (PM2.5)-induced NF-kappaB activation in lung epithelial cells. Toxicol Lett. 2004;14:95-102.

49. Tak PP, Firestein GS. NF-kappaB: a key role in inflammatory diseases. J Clin Invest. 2001;107:7-11.

50. Sandireddy R, Yerra VG, Areti A, Komirishetty P, Kumar A. Neuroinflammation and oxidative stress in diabetic neuropathy: futuristic strategies based on these targets. Int J Endocrinol. 2014;2014:674987.

51. Xu X, Deng F, Guo X, Lv P, Zhong M, Liu C, Wang A, Tzan K, Jiang SY, Lippmann M, Rajagopalan S, Qu Q, Chen LC, Sun Q. Association of systemic inflammation with marked changes in particulate air pollution in Beijing in 2008. Toxicol Lett. 2012;212:147-56

52. Zhao Q, Gao C, Cui Z. Ginkgolide a reduces inflammatory response in highglucose-stimulated human umbilical vein endothelial cells through STAT3mediated pathway. Int Immunopharmacol. 2015;25:242-8.

53. Li R, Zhao L, Tong J, Yan Y, Xu C. Fine particulate matter and sulfur dioxide Coexposures induce rat lung pathological injury and inflammatory responses via TLR4/p38/NF-kB pathway. Int J Toxicol. 2017;36:165-73.

54. Cassel SL, Eisenbarth SC, lyer SS, et al. The Nalp3 inflammasome is essential for the development of silicosis. Proc Natl Acad Sci U S A. 2008;105:903540. https://doi.org/10.1073/pnas.0803933105.

55. Sun B, Wang X, Ji Z, Li R, Xia T. NLRP3 inflammasome activation induced by engineered nanomaterials. Small. 2013;9:1595-607.

56. Ma Y, Zhang JX, Liu YN, Ge A, Gu H, Zha WJ, Zeng XN, Huang M. Corrigendum to 'Caffeic acid phenethyl ester alleviates asthma by regulating the airway microenvironment via the ROS-responsive MAPK/Akt pathway. Free Radic Biol Med Free Radic Biol Med. 2016;101:534.

\section{Publisher's Note}

Springer Nature remains neutral with regard to jurisdictional claims in published maps and institutional affiliations. 